\title{
Motivational Factors and Job Performance: The Mediating Roles of Employee Engagement
}

\author{
Hussain Almawali (Corresponding author) \\ Faculty of Business and Management, Universiti Teknologi MARA \\ Jalan Ilmu 1/1, 40450 Shah Alam, Selangor, Malaysia \\ Dr Nor Intan Adha Hafit \\ Faculty of Business and Management, Universiti Teknologi MARA \\ Jalan Ilmu 1/1, 40450 Shah Alam, Selangor, Malaysia \\ Prof. Dr Narehan Hassan \\ Faculty of Business and Management, Universiti Teknologi MARA \\ Puncak Alam, 42300 Kuala Selangor, Selangor, Malaysia
}

Received: May 20, 2021 Accepted: Jun. 25, 2021 Online published: Jul. 12, 2021

doi:10.5296/ijhrs.v11i3.18856 URL: https://doi.org/10.5296/ijhrs.v11i3.18856

\begin{abstract}
This research examines the relationship between motivational factors, job performance, employee engagement and the impact of motivational factors on job performance function of employee engagement as a mediator in the government sector in the Sultanate of Oman. A quantitative study methodology was used, and six hypotheses were evaluated using 111 representative government employees from the Ministry of Education. This study is a pilot test. This study uses quota sampling, and Statistical Package for the Social Sciences (SPSS) and path analysis techniques were used for the analysis. The study's findings indicate that these factors have a favorable association, that motivational factors have significant positive relationships with employee engagement and job performance, and that employee engagement acts as a partial mediator in the relationship between motivational factors and job performance. This study is critical for leaders and regulators interested in enhancing job performance in Oman's public sector. This is one of the few studies on the mediating function of employee engagement in the link between motivational variables and job performance.
\end{abstract}


This is the first research of its kind in Oman for the public sector. Other motivational variables could be examined and evaluated in the private sector in Future research.

Keywords: motivational factors, job performance, employee engagement, government sector in the Sultanate of Oman

Performance in the institutional context is a major factor in managing employees (June \& Mahmood, 2011) and has become a critical element in an enterprise's performance (Ahmad et al., 2018). Enhancing workforce success through effective communication and motivating strategies is a primary objective of the institution's leadership (Ahmed et al., 2016). Employee success is critical to achieving an organization's purpose and business objectives and employee efficiency is a critical factor in an institution's growth (June et al., 2013). To reach these goals, the company's regulatory authority implements numerous strategies and practices to optimize efficiency under a variety of operational environments and to achieve the best possible results for the organization by relying on the efforts of employees (Ahmed et al., 2016). Key workers are vital to achieving targets (Mohamed et al., 2020). Improved efficiency results in decreased organizational challenges. Employees are an institution's most valuable commodity (Detienne et al., 2020).

Numerous studies have shown a clear correlation between job satisfaction and job performance (Anitha, 2014; e.g., Gorgievski et al, 2010; Dajani, 2015; Ismail et al., 2019). Several studies have shown that interaction improves outcomes. Without regard for work success, organizations would be unable to energies and motivate employees for target accomplishment (Dess et al., 2006; Ghaffari et al., 2017). Psychologists believe that as companies place a higher premium on employee success by motivation and engagement, they would be well equipped to motivate people to achieve goals (Aarabi et al., 2013). According to Detienne et al. (2020), communicating the optimistic value of tasks as a motivating resource to engage employees is significantly more effective than discussing the negative consequences of an incomplete job, and framing tasks and jobs in terms of rewards significantly increases their expected attractiveness and inner drive.

Work output is described and interpreted differently in science and industrial fields. Lawler and Porter (1967) described job performance as the contribution of an individual's abilities, skills, and effort to a particular situation. Bernardin and Beatty (1984) described job performance as a database of a work process's or activity's outputs over a specified period. Hunter (1986) described job output as the result of an employee's Labour. Campbell (1990) described job success as the actions or behaviors that contribute to the achievement of the company's objectives and employee success as the consolidated financial or nonfinancial contribution added by employees to the accomplishment of the business's goals both internally and externally. Borman and Motowidlo (1993) described job performance as having three critical components: (a) defined in terms of behavior rather than consequences, (b) limited to tasks critical to the institution's goals, and (c) being a multidimensional concept. Viswesvaran and Ones (2000) described job performance as the adaptive actions, behaviors, and outcomes that employees participate in or bring about that contribute to the achievement of institutional objectives. According to Price (2001), employee output is an individual's good 
alignment with their work. Performance is the monetary worth of a person's or team's work (Reynoldsa et al., 2020). Griffin (2007) described job output as the number of activities and behaviors performed by employees. Pushpakumari (2008) described job output as an application of the principle of effort to the worker's mission. Additionally, Addair et al., (2019) described job success as the value that workers bring to the organization that employs them. An individual's job success is measured by the degree to which duties and responsibilities are performed. The number of jobs and the nature of the work are the two primary factors to remember when determining job results (Reynoldsa et al, 2020). Addair et al., (2019) described job performance as all employees' activities and practices that may influence the recruiting institution's outcomes. Job output can be described as the behavior of employees that affects the institution's outcomes (Jalalkamali et al., 2016). Employee success is a complex and nuanced phenomenon in contemporary society, formed by the network of shared values, roles, and aspirations through cultures (Aliekperova, 2018).

Numerous factors affect job results, including the person and the work climate (Tripathy, 2013). Tamkin (2005) asserted that collaboration would improve job efficiency. Outstanding skills and preparation result in an increase in organizational success (Misra, 2013). Searle et al. (2001) contended that social assistance would help workers perform better. George (2000) claimed that emotional intelligence is a factor in work success. According to Ghaffari et al. (2017), work efficiency improved as a result of the following factors: pay, fringe benefits, monitoring, advancement, accountability, and preparation. Aarabi et al. (2013) said career performance variables include compensation, job protection, advancement, freedom, a comfortable work climate, and preparation. Dajani (2015) discovered that the factors of leadership, organizational fairness, wages and rewards, work practices and processes, and preparation all had an impact on job efficiency. Numerous hypotheses address human desires, like Herzberg's two-factor hypothesis, Vroom's expectancy theory, and Maslow's desire theory (Ghaffari et al., 2017).

This analysis aims to determine the connection between job performance and motivating factors (training and compensation). This research investigates the functions of employee engagement as a moderator in the partnership between training, compensation, and work performance. This study has focused on the government sector in the Sultanate of Oman, and the case study was the Ministry of Education.

\section{Problem of the Study}

Many countries and organizations worldwide have faced economic challenges as a consequence of low job performance. According to a survey conducted by Blue Cross Blue Shield, depression diagnoses among millennials and teenagers are growing at a faster pace than in any previous generation. In any event, the condition is estimated to cost $\$ 44$ billion annually in lost productivity in the United States alone (Detienne et al., 2020).

In reality, Oman still struggles with job performance in the government sector. There are currently no reliable performance metrics in the public sector. Whatever mechanism is used, whether institutional or human, performance is low (Orabi, 2020). Diversifying the economy and increasing the national GDP will be impossible unless government units improve their 
performance (Orabi, 2020). Implementing efforts and programs to improve performance in the government sector is critical (Almatani, 2020).

This study is intended to build a more in-depth view of training and compensation as motivation that impacts workplace performance in the context of the Sultanate of Oman government sector using the Ministry of Education as a case study. Decision makers in the Sultanate of Oman's government sector may benefit from this research in terms of developing policies and methods to inspire and encourage their employees to continue achieving organizational goals.

In addition, the present research extends knowledge and better understanding of the link between motivation and performance through the mediating function of employee engagement.

\section{Literature and Hypotheses Development}

\section{Government sector in the Sultanate of Oman}

The Sultanate of Oman is an Arab Muslim country in western Asia located on the Arabian Peninsula. It has a total population of roughly 4.6 million people, of which only $58 \%$ are Omanis, and the rest are foreigners. The Sultanate of Oman is classified as a Sultanate with a middle-range income. Oman's revenues are based on oil and gas as the principal sources of income. In 2019, almost 2.4 million people were employed in Oman. The Sultanate of Oman comprises 15 authorities and 23 ministries, all of which are governed by labor legislation (National Centre for Statistics and Information [NCSI], 2019).

\section{Motivational Factors and Employee Engagement}

There are several motivational factors. Training and compensation will be studied in this research as motivational factors. Training is an essential part of employee performance because it allows workers to focus on the most important aspects of their job (Dajani, 2015). Training and education may be used as a motivation to encourage employee development and improve personal employment goals by fulfilling fundamental human needs such as the desire for stability, teamwork, and skills (Khan, 2012). The findings of Oyovwe et al., (2021) revealed a substantial association between training and work performance. Additionally, quality training will reduce learning durations, encourage training transfer to the workplace, and increase workers' enthusiasm to transmit training results to the organization (Garavan et al., 2020).

Compensation can be a huge motivator for leaders (Rasheed et al., 2016). The authors found that poor earnings contribute to stress. Compensation is the primary measure of motivation since people often accomplish more than they expect in exchange for their efforts (Bao \& Nizam, 2015). In reality, "compensation" encompasses both monetary and nonmonetary rewards. Swapna and Narayanamma (2019) investigated the influence of monetary and nonmonetary incentives on employee performance and satisfaction. They discovered that top-level employees are more satisfied and perform better with nonmonetary incentives, but lower-level employees are more satisfied and perform better with monetary incentives. Oetomo et al. (2020) found compensation had a substantial influence on employee anxiety; 
compensation had a substantial influence on job performance, and anxiety had a substantial influence on job performance. Therefore, hypotheses 1 and $2(\mathrm{H} 1 \& \mathrm{H} 2)$ are as follows:

H1: There is a significant relationship between training and job performance.

H2: There is a significant relationship between compensation and job performance.

\section{Employee Engagement and Job Performance}

When employees are engaged, they recruit and combine various aspects of their cognitive and psychological self to transform their job tasks and special interactions into concrete accomplishments (Byrne, 2014). Unlike disengaged employees, those with a high level of involvement are enthusiastic about their employment, focused on their professions, and demonstrate their dedication to their organizations (Ismail et al., 2019).

Parker and Griffin (2011) demonstrated that organizational commitment results in increased job performance by fostering constructive emotions and increasing passion for finishing work assignments and responsibilities. Employee motivation clearly affects job outcomes (Stairs \& Galpin, 2009). Evidence-based research showed that worker involvement directly impacts job success (Ismail et al., 2019). Gorgievski et al. (2010), for example, used a multidimensional analysis to examine the relationship between employee involvement and achievement among 54 Dutch educators. They discovered a positive bond. This result is consistent with Gorgievski et al. (2010), who evaluated 2,162 staff over 1.5 years and discovered that employee conduct has a significant impact on the project and qualitative results. Anitha (2014) and Ismail et al. (2019) reiterated their findings of the close association between employee motivation and work success. Many previous studies have found a direct correlation between employee motivation and job success because dedicated employees are expected to perform more than others (Demerouti \& Cropanzano, 2010). Therefore hypothesis 3 (H3) is as follows:

H3: There is a significant relationship between employee engagement and job performance.

\section{Motivational Factors and Employee Engagement}

The Motivating elements of training and compensation vary. Because of its beneficial correlation with employee performance, the notion of training has grown in prominence within human resources (Baker \& Asiimwe, 2014). Training is a component of capacity development in any business that aims to boost employee performance, enhance employee engagement, and help the business to accomplish its goals (Tahir et al., 2014). Staff training typically results in a long-term shift in employee behavior in the form of greater productivity. Training is primarily focused on the development and enhancement of workers' experience and competencies that eventually contribute to work performance through increased employee engagement. Training is a critical component in increasing employee engagement. When workers get enough training on how to control their tension at work or home, they become more effective and engaged in their work. Training has a tremendous impact on an organization's employee engagement. Thus, by offering the appropriate training, employee engagement may be favorably impacted (Azeem et al., 2013). Sendawula et al., (2018) found 
a strong association between training and employee engagement.

Compensation has a critical role in employee engagement. It offers both monetary and nonmonetary rewards, including recognition and benefits such as worker support services, free eating facilities, transit coupons, flexible work hours, and longer vacations (Anitha, 2014). When workers are happy with their payment and recognition inside their firm, the majority of workers react with high engagement (Saks, 2006). Dajani (2015) indicated that a lack of adequate financial incentives might potentially result in burnout. Zacher et al. (2015) confirmed that compensation has a significant positive influence on employee engagement. Therefore, hypotheses 4 and 5 (H4 \& H5) are as follows:

H4: There is a significant relationship between training and employee engagement.

H5: There is a significant relationship between compensation and employee engagement.

Additionally, organizations use a variety of resources to foster interaction to maintain efficiency and improve outcomes (Dajani, 2015). Employee commitment results in increased workplace success by eliciting optimistic emotions and increasing enthusiasm for job duties and responsibilities (Ismail et al., 2019). When workers are happy with their pay and recognition within their company, most employees react with a high commitment (Saks, 2006). Economic incentives hugely impact workers' productivity and success (Swapna \& Narayanamma, 2019). Numerous companies have used cash incentives to motivate and retain staff as well as to increase their efficiency (Woodruffe, 2000; Cappelli, 2000; Mehrzi, \& Singh, 2016). Many companies use cash incentives as a tool to boost workforce satisfaction and productivity (Hongal et al., 2020).

The commitment benefit is the greatest potential benefit to an organization as it directly impacts how employees do their duties and results in increased engagement in a supportive work climate (Dajani, 2015; Ahakwa et al., 2021). Leaders may make a significant contribution to fostering a healthy work climate that increases employee motivation and results in improved job efficiency (Kahn, 1990; May et al., 2004). The job climate is a significant motivator and includes "working environments, tools available to them, and administrators' ethical behavior" (Rasheed et al., 2016, p. 109). By maintaining an appropriate work climate, job efficiency may be improved (Shah et al., 2010). Employees become invested as they feel secure in the leadership and encouraging environment at work. These both contribute to mental and emotional protection (Koyuncu et al., 2006; May et al., 2004). Dajani (2015) and Ahmed et al. (2016) confirmed the mediating effect of employee engagement between training, compensation, and job performance. Therefore, hypothesis 6 (H6) is as follows:

H6: Employee engagement mediates the relationship between motivational factors and job performance.

\section{Conceptual framework}

This study hypothesized that job performance as a dependent variable has significant relationships with employee engagement and motivational factors. The conceptual model also has employee engagement as a mediator. Figure 1 shows the conceptual framework of this 
study.

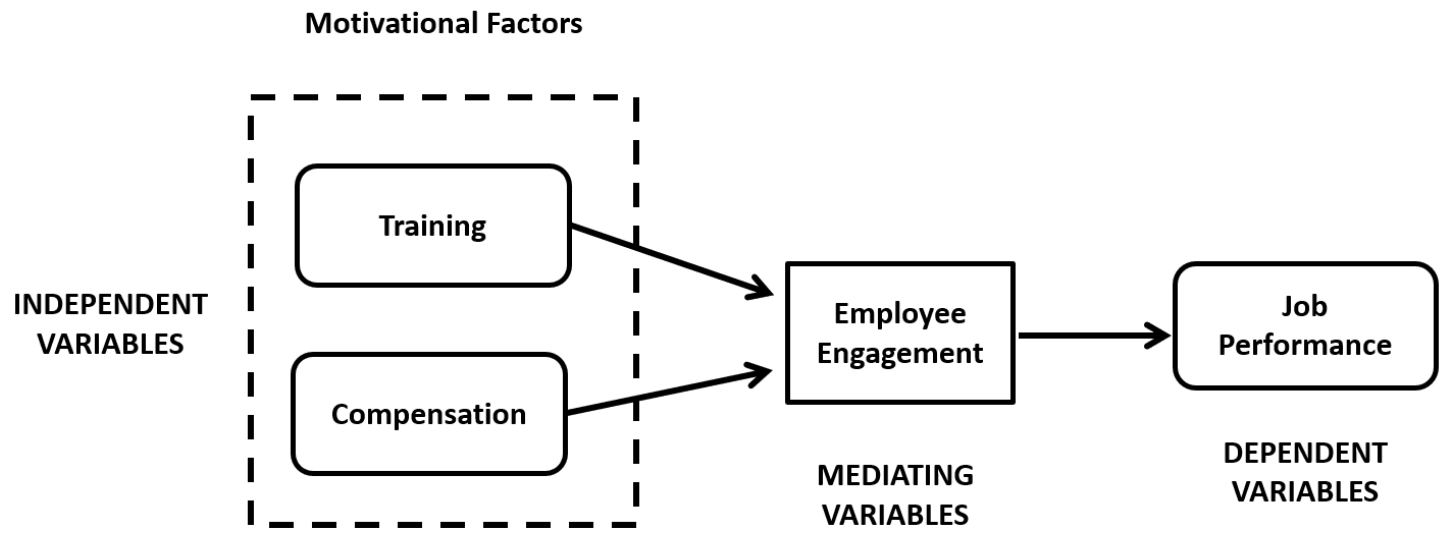

Figure 1. Research Framework

\section{Method}

This paper used a causal descriptive quantitative analysis approach based on a summary of the literature. Descriptive statistics are used to describe conclusions, precisely how workers interpret the actions under investigation, while causal statistics are used to illustrate the causal model of variables. SPSS and path analysis techniques were used for the analysis. Path mapping is often used to describe both primary and indirect partnerships (Riduwan, 2012).

\section{Population}

A population is a group of anticipated participants to whom the researcher seeks to generalize the research's results (Shepherd et al., 2017). This study was a pilot test. The population for this study is the present workers of the Ministry of Education. These government workers will be operationally defined as those who work in a ministry and have completed the 1-year work experience requirement.

\section{Sampling methods}

"Sampling" refers to the process of selecting an acceptable quantity of correct things from a population (Sekaran \& Bougie, 2010). The sampling technique used to identify participants in this study was quota sampling, which often permits the author to exercise very limited control over the survey's selectivity, allowing the research to eliminate bias during the selection step. This study's quota was determined by the number of Ministry of Education workers with 1 year of work experience.

\section{Sample size}

The total number of participants was 111 employees. Krejci and Morgan (1970) served as a guide for establishing an appropriate sample size for the study population that ended up being 111 individuals. The sample size is 111 workers, using the Krejcie-Morgan formula. Hair et al. (2010) proposed that a minimum of 100 responders be analyzed. 


\section{Macrothink}

International Journal of Human Resource Studies

ISSN 2162-3058

2021, Vol. 11, No. 3

\section{Validity}

Content validity, also known as face validity, is a subjective assessment of the degree of connection between the scale's items and its theoretical explanation (Hair et al., 2010). The current research examines content validity by analyzing how well the items assessed covered all parts of the topic.

\section{Reliability}

"Reliability" refers to the degree to which a measurement remains consistent over time, or the duration of time during which results may be replicated (Bryman, 2008). George and Mallery's (2010) "rules of thumb" were used to assess these analytic results. The outcomes of the study's reliability evaluation that included employee engagement, work performance, and motivating factors, are presented in Table 3.8. The findings of the investigation indicated that the instrument was appropriate for this study. The researcher determined what things will be used. Cronbach's Alpha values of $>0.8$ were found for employee engagement, motivating variables, and work performance, indicating the measurement's strong and positive correlation.

Table 1. Findings of Reliability Analysis

\begin{tabular}{ll} 
Variables & Cronbach's Alpha value \\
\hline Employee & \\
Engagement & 0.921 \\
\hline Motivational Factors & 0.935 \\
\hline Job Performance & 0.923 \\
\hline
\end{tabular}

Table 2. Demographic Characteristics

\begin{tabular}{|c|c|c|c|}
\hline Demography & Category & Respondents & $\%$ \\
\hline \multirow{2}{*}{ Sex } & male & 70 & $63 \%$ \\
\hline & female & 41 & $37 \%$ \\
\hline \multirow{5}{*}{ Age } & $<25$ & 0 & $0 \%$ \\
\hline & $>26-35$ & 34 & $31 \%$ \\
\hline & $>36-45$ & 77 & $69 \%$ \\
\hline & $>46-55$ & 0 & $0 \%$ \\
\hline & $>56$ & 0 & $0 \%$ \\
\hline \multirow{5}{*}{ Education } & High School Degree & 0 & $0 \%$ \\
\hline & $\begin{array}{l}\text { University Degree (Diploma } \\
\text { \& Bachelor) }\end{array}$ & 2 & $2 \%$ \\
\hline & Master Degree/MBA & 74 & $67 \%$ \\
\hline & $\mathrm{PhD}$ & 35 & $31 \%$ \\
\hline & Other Degrees & 0 & $0 \%$ \\
\hline \multirow{5}{*}{ Tenure } & $<5$ years & 3 & $3 \%$ \\
\hline & $>6-10$ years & 16 & $14 \%$ \\
\hline & $>11-15$ years & 33 & $30 \%$ \\
\hline & $>16-20$ years & 38 & $34 \%$ \\
\hline & $>21$ years & 33 & $30 \%$ \\
\hline
\end{tabular}

This research applied the questionnaire procedure through which surveys are distributed and 
was formed from employee engagement thought Rich et al. (2010), job performance based on Ramos et al. (2019), training based on Majdalawi (2015). Every query was created using a Likert scale $(1-6)$. This study spread 130 questionnaires and collected 111 useable responses. This indicates the institution's labor demographic. The majority of the participants were male (70) with 41 females. Most of the respondents held a master's degree and PhD. Nearly $71 \%$ of the employees had served the ministry for more than 16 years.

Cronbach's alpha was used to check the reliability of the items, the majority of which were recommended as excellent with a Cronbach's Alpha value of more than 0.9; all variables are accurate. This research used the bootstrapping procedure macro to determine the importance of indirect impacts (Hayes, 2018). Bootstrapping is a typical way to avoid sample assumptions (Kozlov et al., 2019).

\section{Finding}

The relationships between constructs are shown in Table 3 along with their means and standard deviations. Found that employee engagement is linked to employee motivation (training and compensation). With substantial research evidence supporting the claim, it can be confirmed that employee engagement is favorably influenced by motivating variables $(\beta=$ $0.435, \mathrm{SE}=0.121, \mathrm{p}=0.00$ ) that collaborate to maintain $\mathrm{H} 1$ and $\mathrm{H} 2$. Results have shown that job performance is influenced positively by motivating variables $\beta=-0.085, \mathrm{SE}=0.127, \mathrm{p}=$ 0.00) that collaborate to maintain $\mathrm{H} 3$, and results have shown that job performance is influenced positively by employee engagement $(\beta=0.734, \mathrm{SE}=0.072, \mathrm{p}=0.00)$ in the government sector in the Sultanate of Oman. This supports H4 and H5.

Table 3. Correlation

\begin{tabular}{|c|c|c|c|c|c|c|}
\hline & \multicolumn{3}{|c|}{ Motivational Factors } & \multicolumn{3}{|c|}{ Employee Engagement } \\
\hline & Coeff & SE & p-value & Coeff & SE & p-value \\
\hline \multicolumn{7}{|l|}{ Employee } \\
\hline Engagement & 0.435 & 0.121 & 0.000 & - & - & - \\
\hline Job Performance & -0.085 & 0.127 & 0.000 & 0.734 & 0.072 & 0.000 \\
\hline \multirow[t]{4}{*}{ Constant } & 1.733 & 0.462 & 0.000 & 1.601 & 0.332 & 0.000 \\
\hline & R Square & 0.153 & & R Square & 0.485 & \\
\hline & $\mathrm{F}=$ & 9.778 & & $\mathrm{~F}=$ & 102.729 & \\
\hline & $\mathrm{P}=$ & 0.000 & & $\mathrm{P}=$ & 0.000 & \\
\hline
\end{tabular}

Table 4 shows that their relevance assessment is used to evaluate whether the mediation of employee engagement exists in the relationship between job performance and motivational factors. In conclusion, job performance is impacted by motivating variables that operate indirectly (This collaborates to maintain H4 \& H5.), and the impact predicted is $(\beta=0.2686)$. There are also typical error and confidence intervals to bootstrap from the starting point. The indirect impact has a b-value ranging between 0.1243 and 0.4410 . A 0 (indicating a positive indirect impact) and is not included in this scale because it shows anticipated results. Employee engagement is a factor that connects the things that motivate people and their work performance; this collaborates to maintain H6. 
Table 4. Indirect Effect of Employee Engagement in the Relationship Between Motivational Factors and Job Performance

Effect of Motivational Factors on Job Performance

\begin{tabular}{lcccc}
\hline & Effect & Boot SE & BootLLCI & BootULCI \\
\hline $\begin{array}{l}\text { Motivational Factors -> } \\
\text { Employee Engagement }\end{array}$ & 0.2686 & 0.0808 & 0.1243 & 0.4410 \\
-> Job Performance & & & & \\
\hline
\end{tabular}

\section{Discussion}

This research was obtained to explain the correlation between motivational factors, employee engagement, and job performance, and the effect of motivational factors on these variables in the government sector of Oman. There is a connection between various variables, particularly motivating elements with employee engagement and job performance

The preceding findings are generally compatible with Aarabi et al.'s (2013) study at Malaysian service industry that motivational factors relate to job performance, in line with Mensah and Tawiah (2016) at mining companies in Ghana, and Ghaffari et al. (2017) with a case study at the Universiti Teknologi Malaysia, who found there was a significant and positive relationship between motivations and job performance. Moreover, Anitha (2014) found there was a significant and positive relationship between engagement and job performance. Similar to the findings by Aguenza et al (2018), research showed that when there is a link between a person's interests and their motivation, engagement is likely Additional empirical evidence for the claim that motivation has a strong effect on work performance has been found (Ghaffari et al., 2017).

The conclusions of this research confirm that the mediator may affect the relationship between independent and dependent variables. Because these variables have a role in predicting work performance, this study predicts that employee engagement is a partial mediator for motivational variables and overall work success, as confirmed by Dajani (2015) and Ahmed et al. (2016). Motivation is so powerful is affects both work performance and employee engagement. Additionally, this implies that the employee's work performance, as well as directing practices, may assist managers in including motivational aspects that may be reinforced and fueled by employee involvement.

This work has some limitations; the data collected do not include all layers of government. Common technique bias cannot be eliminated because the data used in this research were gathered at a single moment in time from a single source; nevertheless, potential research could gather repeated sampling from the same population periodically over a prolonged period.

Overall, this research outcome confirmed from all aspects a strong connection among motivational factors, employee engagement, and job performance for employees in the government sector of the Sultanate of Oman. A manager who implements the dimension of motivational factors will increase job performance. In this way, employee engagement acts as 
a buffer between the variables of motivational elements and work performance.

\section{Recommendations for future research}

The purpose of this study was to examine two motivating factors: training and remuneration and their link to job performance and employee engagement. There is little research on employee engagement's mediating effect. Further research may be conducted to examine other motivating variables. Additionally, the present study's findings should be validated in the private sector.

\section{References}

Aarabi, M. S., Subramaniam, I. D., \& Akeel, A. B. A. A. B. (2013). Relationship between motivational factors and job performance of employees in malaysian service industry. Asian Social Science, 9(9), 301-310. doi:10.5539/ass.v9n9p301

Addair, Angela Michelle, "Retail Employee Motivation and Performance" (2019). Walden $\begin{array}{llll}\text { Dissertations } & \text { and } & \text { Doctoral } & \text { Studies. }\end{array}$ https://scholarworks.waldenu.edu/dissertations/7453

Aguenza, B. B., \& Som, A. P. (2018). Motivational Factors of Employee Retention and Engagement in Organizations.

Ahmad, A., Ibrahim, R., \& Bakar, A. (2018). Factors influencing job performance among police personnel: An empirical study in Selangor.Management Science Letters, 8(9), 939-950. https://doi.org/10.5267/j.msl.2018.6.014

Ahmed, S., Ahmad, F. B., \& Raihan Joarder, M. H. (2016). HRM Practices-Engagement-Performance Relationships: A Conceptual Framework for RMG Sector in Developing Economy. Mediterranean Journal of Social Sciences, 7(4), 87. https://doi.org/10.5901/mjss.2016.v7n4p87

Ahakwa, I., Yang, J., Tackie, E. A., \& Atingabili, S. (2021). The Influence of Employee Engagement, Work Environment and Job Satisfaction on Organizational Commitment and Performance of Employees: A Sampling Weights in PLS path Modelling. https://doi.org/10.33215/sjom.v4i3.641

Al Mehrzi, N., \& Singh, S. (2016). Competing through employee engagement: a proposed framework. International Journal Of Productivity And Performance Management, 65(6), 831-843. doi: 10.1108/ijppm-02-2016-0037

Aliekperova, N. (2018). Motivating Factors Effecting Work Efficiency of Employees in Ukrainian Pharmaceutical Sector. Economics \& Sociology, 11, 61-74. https://doi.org/10.14254/2071-789X.2018/11-1/4

Alderfer, C. P. (1972). Existence, relatedness, and growth: Human needs in organizational settings. New York: Free Press.

Anitha, J. (2014). Determinants of employee engagement and their impact on employee performance. International Journal of Productivity and Performance Management, 63, 308-323. https://doi.org/10.1108/IJPPM-01-2013-0008

Azeem, M. F., \& Paracha, A. (2013). Connecting Training and Development with Employee Engagement: How Does it Matter? 


\section{Mll Macrothink}

International Journal of Human Resource Studies

ISSN 2162-3058

2021, Vol. 11, No. 3

Baker, S., \& Asiimwe, S. B. (2014). Does training influence employee performance in regulatory organizations in Uganda? Empirical evidence from UCC.

Bao, C., \& Nizam, I. (2015). THE IMPACT OF MOTIVATION ON EMPLOYEE PERFORMANCE IN THE ELECTRONICS INDUSTRY IN CHINA. https://doi.org/10.24924/ijabm/2015.11/v3.iss2/29.45

Bernardin, H. J., \& Beatty, R. (1984). Performance appraisal: assessing human behavior at work.

Bhuvanaiah, T. (2014). Employee Engagement: Key to Organizational Success. SCMS Journal of Indian Management.

Borman, W. C., \& Motowidlo, S. (1993). Expanding the Criterion Domain to Include Elements of Contextual Performance.

Bryman, A. (2008). Social research methods (3rd ed.). Oxford: Oxford University Press.

Byrne, Z. S. (2014). Understanding Employee Engagement: Theory, Research, and Practice. https://doi.org/10.4324/9780203385944

Campbell, J. P. (1990). Modeling the performance prediction problem in industrial and organizational psychology.

Cappelli, P. (2000). A Market-Driven Approach to Retaining Talent. Harvard Business Review, 78.

Dajani, Z. (2015). The impact of employee engagement on organisational performance. South African Institute for Chartered Accountants Conference, 3(5), 288-295.

Demerouti, E., \& Cropanzano, R. (2010). From thought to action: employee work engagement and job performance.

Dess, G. G., Peridis, T., \& Lumpkin, G. T. (2006). Strategic management: Creating competitive advantages. Toronto: McGraw-Hill Ryerson.

DeTienne. K, Hooley. J, Larrocha. C, Reay. A. (2020). How to manage an employee with depression. Harvard Business Review. https://hbr.org/2020/01/how-to-manage-an-employee-with-depression

Garavan, T., McCarthy, A. M., Lai, Y., Murphy, K., Sheehan, M., \& Carbery, R. (2020). Training and organisational performance: A meta-analysis of temporal, institutional, and organisational context moderators. Human Resource Management Journal. https://doi.org/10.1111/1748-8583.12284

George, J. (2000). Emotions and Leadership: The Role of Emotional Intelligence. Human Relations, 53, 1027 - 1055. https://doi.org/10.1177/0018726700538001

George, D., \& Mallery, P. (2010). SPSS for Windows step by step: A simple guide and reference.

Ghaffari, S., Shah, I., Burgoyne, J., Nazri, M., \& Salleh, J. R. (2017). The Influence of Motivation on Job Performance: A Case Study at Universiti Teknoligi Malaysia. Development Economics: Regional \& Country Studies eJournal.

Gorgievski, M., Bakker, A., \& Schaufeli, W. (2010). Work engagement and workaholism: comparing the self-employed and salaried employees. The Journal of Positive Psychology, 5, 83 - 96. https://doi.org/10.1080/17439760903509606 
Griffin, M., Neal, A., \& Parker, S. (2007). A new model of work role performance: Positive behavior in uncertain and interdependent contexts. Academy of Management Journal, 50, 327-347. https://doi.org/10.5465/amj.2007.24634438

Hair, J. F., Black, W. C., \& Babin, B. J. (2010). Multivariate Data Analysis: A Global Perspective (7th ed.).

Hayes, A. (2018). Partial, conditional, and moderated moderated mediation: Quantification, inference, and interpretation. Communication Monographs, $85, \quad 4 \quad-40$. https://doi.org/10.1080/03637751.2017.1352100

Herzberg, F., Mausner, B., \& Snyderman, B. B. (1959). The motivation to work.

Hicks, R., O'Reilly, G., \& Bahr, M. (2014). Organisational engagement and its driving forces: A case study in a retail travel organisation with international outreach. International journal of management cases, 16, 4-19.

Holston-Okae, B. L. (2017). Employee Turnover Intentions in the Hospitality Industry.

Hongal, P., \& Kinange, U. (2020). A Study on Talent Management and its Impact on Organization Performance- An Empirical Review. International Journal of Engineering and Management Research, 10, 64-71. https://doi.org/10.31033/ijemr.10.1.12

Hunter, J. (1986). Cognitive ability, cognitive aptitudes, job knowledge, and job performance. Journal of Vocational Behavior, 29, 340-362. https://doi.org/10.1016/0001-8791(86)90013-8

Ibrahim, M., \& Falasi, S. A. (2014). Employee loyalty and engagement in UAE public sector. Employee Relations, 36, 562-582. https://doi.org/10.1108/ER-07-2013-0098

Ismail, H., Iqbal, A., \& Nasr, L. (2019). Employee engagement and job performance in Lebanon: the mediating role of creativity. International Journal of Productivity and Performance Management, 68, 506-523. https://doi.org/10.1108/IJPPM-02-2018-0052

Jalalkamali, M., Ali, A., Hyun, S. S., \& Nikbin, D. (2016). Relationships between work values, communication satisfaction, and employee job performance. Management Decision, 54, 796-814. https://doi.org/10.1108/MD-01-2015-0003

June, S., Kheng, Y. K., \& Mahmood, R. (2013). Determining the Importance of Competency and Person-Job Fit for the Job Performance of Service SMEs Employees in Malaysia. Asian Social Science, 9, 114. https://doi.org/10.5539/ass.v9n10p114

June, S., \& Mahmood, R. (2011). Exploring The Relationship Between Role Ambiguity And Job Performance Among Employees Of The Service Sector Smes In Malaysia.

Jung, H., \& Yoon, H. (2018). Improving frontline service employees' innovative behavior using conflict management in the hospitality industry: The mediating role of engagement. Tourism Management, 69, 498-507. https://doi.org/10.1016/j.tourman.2018.06.035

Kahn, W. A. (1990). Psychological Conditions of Personal Engagement and Disengagement at Work. Academy of Management Journal, 33, 692-724. https://doi.org/10.5465/256287

Karatepe, O. M., Keshavarz, S., \& Nejati, S. (2010). Do core self-evaluations mediate the effect of coworker support on work engagement? A study of hotel employees in Iran. Journal of Hospitality and Tourism Management, 17, 62-71. https://doi.org/10.1375/jhtm.17.1.62

Khan, M. I. (2012). The Impact of Training and Motivation on Performance of Employees. Motivation. 
Koyuncu, M., Burke, R., \& Fiksenbaum, L. (2006). Work engagement among women managers and professionals in a Turkish bank. Equality, Diversity and Inclusion, 25, 299-310. https://doi.org/10.1108/02610150610706276

Kozlov, A. M., Darriba, D., Flouri, T., Morel, B., \& Stamatakis, A. (2018). RAxML-NG: A fast, scalable, and user-friendly tool for maximum likelihood phylogenetic inference. bioRxiv. https://doi.org/10.1101/447110

Krejcie, R. V., \& Morgan, D. W. (1970). Determining sample size for research activities. Educational and Psychological Measurement, 30, 607-610. https://doi.org/10.1177/001316447003000308

Kuranchie-Mensah, E. B., \& Amponsah-Tawiah, K. (2016). Employee motivation and work performance: A comparative study of mining companies in Ghana. Journal of Industrial Engineering and Management, 9, 255-309. https://doi.org/10.3926/jiem.1530

Lawler, E., \& Porter, L. (1967). The Effect of Performance on Job Satisfaction. Industrial Relations, 7, 20-28. https://doi.org/10.1111/j.1468-232X.1967.tb01060.x

Lorincová, S., Starchon, P., Weberová, D., Hitka, M., \& Lipoldová, M. (2019). Employee Motivation as a Tool to Achieve Sustainability of Business Processes. Sustainability, 11, 3509. https://doi.org/10.3390/su11133509

Macleod, D. I., \& Clarke, N. (2011). Engaging for success: enhancing performance through employee engagement, a report to Government.

Majdalawi, M. A. (2015). Human resource development in Palestinian higher education, with special reference to evaluation of employee development and training at the Al-Aqsa University, Gaza, Palestinian Authority.

Maslow, A. H. (1943). A theory of human motivation. Psychological Review, 50(4), 370. https://doi.org/10.1037/h0054346

May, D. R., Gilson, R., \& Harter, L. (2004). The psychological conditions of meaningfulness, safety and availability and the engagement of the human spirit at work. https://doi.org/10.1348/096317904322915892

Mendes, F., \& Stander, M. (2011). Positive organisation : the role of leader behaviour in work engagement and retention : original research. Sa Journal of Industrial Psychology, 37, 1-13. https://doi.org/10.4102/sajip.v37i1.900

Misra, S. (2013). A study of organizational commitment of B Ed college teachers in relation to organizational support work life balance and ethical leadership behaviour of their principals.

Mohamed, M. S., Khalifa, G. S., Nusari, M., Ameen, A., Al-Shibami, A. H., \& Abuelhassan, A. (2020). Effect of Organizational Excellence and Employee Performance on Organizational Productivity Within Healthcare Sector in the UAE. Journal of Engineering and Applied Sciences, 13, 6199-6210. https://doi.org/10.36478/jeasci.2018.6199.6210

National Center for Statistics and Information [NCSI] (2019) Statistical Year Book for the Year 2019. Muscat. Retrieved December 6, 2019, from https://www.ncsi.gov.om/Elibrary/LibraryContentDoc/bar_Statistical Year Book 2019_c2111831-e13a-4075-bf7b-c4b5516e1028.pdf 


\section{$\triangle$ Macrothink}

International Journal of Human Resource Studies ISSN 2162-3058

Oetomo, H. W., \& Budiyono. (2020). Work Motivation and Compensation Towardswork Stress And Employee Performance. https://doi.org/10.5373/JARDCS/V12SP1/20201123

Orabi, K. (2018). Performance indicators are absent in the government sector...weak in the private sector. Retrieved April 6, 2018 from https://shabiba.com/article/93145-\%D9\%85

Oyovwe-Tinuoye, G. O., Omeluzor, S. U., \& Patrick, I. O. (2021). Influence of ICT skills on job performance of librarians in university libraries of South-South, Nigeria. Information Development. https://doi.org/10.1177/0266666920983393

Parker, S., \& Griffin, M. (2011). Understanding active psychological states: Embedding engagement in a wider nomological net and closer attention to performance. European Journal of Work and Organizational Psychology, 20, 60 - 67. https://doi.org/10.1080/1359432X.2010.532869

Preacher, K., Rucker, D., \& Hayes, A. (2007). Addressing Moderated Mediation Hypotheses: Theory, Methods, and Prescriptions. Multivariate Behavioral Research, 42, 185 - 227. https://doi.org/10.1080/00273170701341316

Price, J. L. (2001). Reflections on the determinants of voluntary turnover. International Journal of Manpower, 22, 600-624. https://doi.org/10.1108/EUM0000000006233

Pushpakumari, M.D. (2008). THE IMPACT OF JOB SATISFACTION ON JOB PERFORMANCE: AN EMPIRICAL ANALYSIS.

Ramos-Villagrasa, P. J., Barrada, J., Fernández-Del-Río, E., \& Koopmans, L. (2019). Assessing job performance using brief self-report scales: the case of the individual work performance questionnaire. Revista de Psicología del Trabajo y de las Organizaciones, 35, 195-205. https://doi.org/10.5093/jwop2019a21

Rasheed, M. I., Humayon, A. A., Awan, U., \& Ahmed, A. U. (2016). Factors affecting teachers' motivation: An HRM challenge for public sector higher educational institutions of Pakistan (HEIs). International Journal of Educational Management, 30, 101-114. https://doi.org/10.1108/IJEM-04-2014-0057

Reynoldsa, T., Howardc, C., Sjåstadd, H., Zhue, L., Okimotof, T. G., Baumeisterf, R. F., Aquinoc, K., \& Kimg, J. (2020). Organizational Behavior and Human Decision Processes.

Rich, B., Lepine, J. A., \& Crawford, E. R. (2010). JOB ENGAGEMENT: ANTECEDENTS AND EFFECTS ON JOB PERFORMANCE. Academy of Management Journal, 53, 617-635. https://doi.org/10.5465/amj.2010.51468988

Riduwan. (2012). Cara Menggunakan dan Memaknai Path Analysis (Analisis Jalur).

Saks, A. (2006). Antecedents and consequences of employee engagement. Journal of Managerial Psychology, 21, 600-619. https://doi.org/10.1108/02683940610690169

Schaufeli, W., Salanova, M., González-romá, V., \& Bakker, A. (2002). The Measurement of Engagement and Burnout: A Two Sample Confirmatory Factor Analytic Approach. Journal of Happiness Studies, 3, 71-92. https://doi.org/10.1023/A:1015630930326

Searle, B., Bright, J., \& Bochner, S. (2001). Helping people to sort it out: The role of social support in the Job Strain Model. Work \& Stress, 15, 328 - 346. https://doi.org/10.1080/02678370110086768

Sekaran, U., \& Bougie, R. (2010). Research Methods for Business: A Skill Building 
Approach (5th ed.).

Sendawula, K., Kimuli, S. N., Bananuka, J., \& Muganga, G. N. (2018). Training, employee engagement and employee performance: Evidence from Uganda's health sector. Cogent Business \& Management, 5. https://doi.org/10.1080/23311975.2018.1470891

Shah, I.A. (2010). RELATIONSHIP BETWEEN REWARDS AND EMPLOYEE'S PERFORMANCE IN CEMENT INDUSTRY IN PAKISTAN.

Shepherd, K., Kervick, C. T., \& Morris, D. N. (2017). Exploring the Research. https://doi.org/10.1007/978-94-6300-824-2_2

Stairs, M., \& Galpin, M. (2009). Positive Engagement: From Employee Engagement to Workplace Happiness. https://doi.org/10.1093/oxfordhb/9780195335446.013.0013

Stewart, G., \& Brown, K. G. (2008). Human Resource Management: Linking Strategy to Practice. https://doi.org/10.26782/jmcms.2019.10.00051

Swapna, P. (2019). Reward and Recognition Impact on Job Satisfaction and Performance in retail sector: an Empirical Study from Andhra and Telangana.

Tahir, N., Yousafzai, I. K., Jan, S., \& Hashim, M. (2014). The Impact of Training and Development on Employees Performance and Productivity A case study of United Bank Limited Peshawar City, KPK, Pakistan. The International Journal of Academic Research in Business and Social Sciences, 4, 86-98. https://doi.org/10.6007/IJARBSS/v4-i4/756

Tamkin, P. (2005). The contribution of skills to business performance.

Tripathy, M. R. (2013). Book Review: Human Resource Management. Vision: The Journal of Business Perspective, 17, 191 - 192. https://doi.org/10.1177/0972262912483991

Truss, C., Shantz, A., Soane, E., Alfes, K., \& Delbridge, R. (2011). Employee engagement, organisational performance and individual well-being: exploring the evidence, developing the theory. The International Journal of Human Resource Management, 24, 2657 - 2669.

Viswesvaran, C., \& Ones, D. (2000). Perspectives on Models of Job Performance. International Journal of Selection and Assessment, 8, 216-226.

Woodruffe, C. (2000). Winning the Talent War: A Strategic Approach to Attracting, Developing and Retaining the Best People.

Zacher, H., Chan, F., Bakker, A., \& Demerouti, E. (2015). Selection, optimization, and compensation strategies: Interactive effects on daily work engagement.

Zhu, W., Avolio, B., \& Walumbwa, F. O. (2009). Moderating Role of Follower Characteristics with Transformational Leadership and Follower Work Engagement. Group \& Organization Management, 34, 590 - 619.

\section{Copyright Disclaimer}

Copyright for this article is retained by the author(s), with first publication rights granted to the journal.

This is an open-access article distributed under the terms and conditions of the Creative Commons Attribution license (http://creativecommons.org/licenses/by/4.0/). 